\title{
Regulating corporate social responsibility practices of adopting codes of conduct through criminal law
}

Regulating codes of conduct via criminal law

\author{
Lilach Litor \\ Division of Public Law and Public Policy, The Open University of Israel, \\ Ra'anana, Israel
}

\begin{abstract}
Purpose - This paper explores different approaches to regulating corporate social responsibility (CSR) patterns of adopting codes of conduct, and discusses the approach that courts should embrace.

Design/methodology/approach - Case studies from various legal systems will be examined. The paper presents new typology relating to different patterns of the Corporate Social Performance (CSP) model, based on aspects of the CSR pyramid, namely, legislative CSR and ethical CSR. Legislative CSR includes adoption of thin codes which reflect compliance within current legal standards of the criminal code, while ethical CSR includes codes reflecting ethical norms and corporate social citizenship beyond mere compliance. The paper also includes the interplay of different patterns of CSR and three approaches to regulation regarding these patterns. Findings - Both the Israeli negative CSR regulatory approach and the American legislative CSR regulatory approach present difficulties.

Originality/value - The paper introduces a theory for regulating CSR within criminal law, drawing on the pyramid of CSR. It presents an original discussion of distinct approaches to regulation of corporate liability, while further developing the institutional theory of CSR and the interplay of regulation and CSR. The paper suggests a novel solution regarding the regulation and acceptance of CSR: the granting of protection from criminal liability to corporations who adopt CSR.
\end{abstract}

Keywords Codes of conduct, Corporate social responsibility (CSR), Ethical CSR, Legislative CSR,

Regulatory approach, Corporate Social Performance (CSP) model

Paper type Research paper

\section{Introduction}

Companies engaging in corporate social responsibility (CSR) have adopted codes of conduct which include internal standards aimed at ensuring ethical conduct of employees and managers. Following the adoption of these codes, one of the issues raised is whether the state should regulate the self -regulation of corporations and consider them within criminal law in an attempt to enhance the adoption of meaningful codes

CSR practices are often analyzed through the Corporate Social Performance (CSP) model (Carroll, 1979), which is composed of a few categories, including institutional, organizational, and individual levels (Wood, 1991). The paper further develops the institutional theory of CSP, which involves the influence of law and rules, societal legitimacy, and stake holder expectations (Wood, 1991; McBarnet, 2007; Marquis et al., 2007). Based on the CSP model, Carroll presented the pyramid of CSR, which includes four dimensions: economic, legal, ethical, and discretionary (Carroll, 1991; Carroll, 2016).

(C) Lilach Litor. Published in Public Administration and Policy. Published by Emerald Publishing Limited. This article is published under the Creative Commons Attribution (CC BY 4.0) license. Anyone may reproduce, distribute, translate and create derivative works of this article (for both commercial and noncommercial purposes), subject to full attribution to the original publication and authors. The full terms of this license may be seen at http://creativecommons.org/licences/by/4.0/legalcode

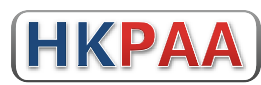
(1) 
PAP

24,1

Drawing on Carroll's pyramid, the paper introduces a typology of CSP practices regarding legislative CSR, as opposed to ethical CSR, thereby further developing aspects of the CSR pyramid. Legislative CSR includes performance aimed at achieving compliance with criminal law standards, whereas ethical CSR reflects the voluntary adoption of ethical norms beyond the standards of the criminal code itself, and an attempt to achieve genuine organizational change.

Scholars have discussed the interplay of regulation and CSR practices (McBarnet, 2007), suggesting that different kinds of regulations may influence the motivation of corporations to adopt CSR practices (Karassin and Bar-Haim, 2015; Karassin and Bar-Haim, 2019). Nevertheless, the current literature does not thoroughly discuss different judicial approaches to regulating CSR within criminal law, nor does it relate to the connection between regulation and different variants of the model of CSP. Moreover, it does not examine how different attitudes towards regulation in criminal law influence the motivation to embrace meaningful patterns of CSR.

The paper aims to bridge that gap by discussing distinct approaches to regulation of corporate liability, based on the different patterns of CSP typology, namely, legislative CSR and ethical CSR. The paper also addresses the gap in how CSR practices are linked to aspects of criminal law by exploring several national approaches, and suggesting a novel solution regarding the regulation of CSR.

The paper looks at the jurisprudence of Israel and the United States as two distinct examples of different approaches to patterns of CSR. Based on analysis of case studies from the two legal systems, the paper points to difficulties arising from the current approaches. It examines the regulation of CSR practices, and discusses whether codes of conduct and compliance programs should be recognized by courts in criminal proceedings. Thus, the research question is: Which judicial approach should be embraced regarding the adoption of codes of conduct?

Several different approaches will be discussed, and a new doctrine will be proposed whereby courts could influence the conduct of corporations by granting protection in exchange for adopting internal mechanisms that enforce fair practices. In order to encourage better ethical environments within corporations, this paper suggests adopting a new approach that would support the regulation of CSR practices within criminal law. Certain codes of conduct and CSR practices could therefore serve as possible protection against criminal liability.

The paper is structured as follows. The first section discusses regulating corporate criminal liability in relation to the different varieties of CSP. It examines traditional state regulation and the development of voluntary practices of CSR. It then presents the typology of CSP practices for codes of conduct, including legislative and ethical CSR, the terms of thick and thin codes, and implications on regulation. The author will discuss the different approaches of regulating CSR regarding codes of conduct, including the negative approach, a legislative CSR regulatory approach, and ethical CSR regulatory approach. The second section presents the American and Israeli systems regarding regulation of CSR practices within criminal law. The third section discusses several approaches and presents justification for the adoption of a new approach towards regulating ethical CSR. The third section also discusses the effect of such regulation on the motivation of corporations to adopt CSR. The fourth section draws on the lines for the suggested approach.

\section{Approaches to regulating corporate criminal liability and types of CSP CSP patterns: legislative CSR, ethical CSR, and corporate social-citizenship} According to the CSP model, Carroll's pyramid of CSR contains a wide base that represents the economic dimension on which the firm is founded (Carroll, 2016). The legal, ethical, and discretionary aspects are located at the base of the pyramid, which consists of economic and for-profit considerations (Carroll, 2000). The discretionary parameters are reflected in 
advancing corporate social citizenship, which entails adopting social responsibility practices towards the community (Carroll, 1999).

The author suggests that different approaches to the regulation of corporations could be connected to different CSP patterns introduced in the paper. I would suggest distinguishing between two different types of a corporation's performance within the CSP model: legislative and ethical CSR. Legislative CSR is a narrow concept, in which the corporation adopts performance standards based on the economic and legislative dimensions of the CSR pyramid. Ethical CSR shares these characteristics, along with ethical and discretionary dimensions as well.

Some corporations adopt basic codes which merely reflect the law, while others adopt meaningful codes which go beyond compliance. Legislative CSR is the adoption of thin codes which aim only at compliance with the demands of the criminal law itself, in addition to fulfilling the economic goals of the firm. Ethical CSR is the embracement of thick codes which adopt ethical norms beyond mere compliance, including the discretionary dimension of corporate social citizenship. Two factors are included: philanthropic activity (Carroll, 1991) and advancing fair behavior to various stakeholders in society, an important factor of CSR according to the stakeholders' theory (Freeman, 1984). The theory of stakeholders posits that firms bear the responsibility to employ fair practices and consider the interests of stakeholders, including customers, suppliers, and the community in general (Karassin and Bar-Haim 2015; 2019). Carroll emphasized that employing meaningful CSR practices requires advancing all of these aspects, including corporate social citizenship (Carroll, 1999).

\section{Different approaches to CSR regulation within criminal law}

Regulation of CSR practices can be accomplished through the mechanism of meta-regulation, which controls the internal self-regulation of corporations (Parker, 2007). Meta-regulation advances the adoption of legal practices aimed at encouraging corporations to take responsibility for their conduct (Lobel, 2004; McBarnet, 2007).

Regarding possible regulation of CSR practices, it is useful to distinguish between three different approaches. Table 1 presents the interplay of CSR regulatory practices within criminal law and CSP patterns.

The negative CSR regulatory approach includes either elements A plus 1 of the matrix above or A plus 2. It posits that the state should refrain from regulating CSR and enhance only the traditional state regulations, while rejecting the consideration of adopting codes of conduct in criminal proceedings.

According to approaches embracing meta-regulation, the existence of CSR practices should be considered in criminal proceedings against corporations. In this vein, the different patterns of CSR have implications on the kind of regulation that should be adopted, depending on whether it is a legislative or ethical approach.

The legislative CSR approach includes elements B plus 1 of the matrix above. This approach only requires compliance programs and adoption of thin codes, which merely reflects the demands of criminal law. It advances the possibility of reduced punishment for corporations upon adoption of such codes, and denies the option of granting corporations protection against criminal liability for adopting codes of conduct. $\begin{array}{ll}\text { A) Not granting protection against criminal } & \text { B) Granting protection against criminal liability upon } \\ \text { liability } & \text { adopting codes }\end{array}$

1-Legislative CSR-Compliance with criminal code
Regulating codes of conduct via criminal law

23


PAP

24,1

Whereas the ethical CSR regulatory approach includes elements B plus 2 of the matrix, it requires the adoption of meaningful codes and social citizenship. The approach posits granting protection against criminal liability to corporations who adopt ethical CSR performance. According to this approach, a code which merely reflects the law itself should not grant protection against criminal liability. The adoption of such a code could not be a basis for a genuine change in the organizational culture. According to this approach, granting protection against liability only on the basis of meaningful codes of conduct will result in avoiding the adoption of codes as a mere attempt to gain legal protection without any real intent to embrace ethical behaviour.

\section{Regulation of CSR practices in the United States and Israel American jurisprudence: adopting a legislative CSR regulatory approach}

American jurisprudence has embraced the legislative CSR regulatory approach. This approach is reflected in the sentencing mitigation doctrine, which considers the adoption of codes and compliance programs in determining sentences (Evans, 2011). According to the sentencing guidelines for organizations (United States Sentencing Commission, 2018), a company with an effective compliance program, including oversight, effective communication to employees with monitoring systems, auditing, reporting and disciplinary mechanisms, may receive a reduction of the basic fine (Haugh, 2017; Wellner, 2005). The sentencing guidelines therefore acknowledge the possibility of granting corporations lighter penalties in exchange for adopting codes of conduct (Bucy, 2009). Yet, corporations have not been granted protection from criminal liability upon adoption of codes of conduct and compliance programs.

In United States v. Ionia Management S.A. (United States Court of Appeal Second Circuit, 2009), the corporation was convicted of violating the act of preventing pollution on ships by failing to maintain an oil record book, despite having a compliance program and code of conduct. The corporation's claim that the crew's actions of discharging waste could not be attributed to the corporation, since they were violating the company's environmental policy, was rejected. The court argued that a compliance program, however extensive, could not immunize the corporation from liability when its employees, acting within the scope of their general authority, fail to comply with the law. Therefore, it could only be considered regarding the sentencing.

The American cases also demonstrate that courts have neither examined the content of the codes, nor have they required meaningful codes as a precondition for granting reduced sentences to corporations. The main demands have been procedural and focused on the existence of an efficient compliance program. Corporations have therefore often adopted codes and compliance programs that were only symbolic and mainly intended to cover evidence (Wellner, 2005).

For instance, in United States v. Caputo (United States District Court for the Northern District of Ilinois, 2006), although the corporation had a compliance program, it was not effective. The court held that the organization subverted the standard compliance goals of crime prevention into ensuring that the corporation could proceed with its illegal marketing scheme, in direct violation of FDA regulations. By applying standards, actions, and expertise within the compliance program, the organization shielded and covered up their offences and the illegal marketing plans.

Furthermore, sentencing guidelines, in fact, compel organizations to adopt a code of conduct. According to sentencing guidelines, courts take into account the avoidance of compliance programs when determining the severity of the fines. The Sarbanes Oxley Act of 2002 also requires supervision of senior management and adequate financial reporting in publicly owned corporations, and holds senior management liable for false or inadequate 
reporting. It includes the requirement that public corporations adopt codes of conduct (Bucy, 2009).

Moreover, corporations have often been required to adopt compliance programs and codes through deferred and non-prosecution agreements (DPA/NPA). In many cases the prosecution has settled a case instead of prosecuting it (Gallo and Greenfield, 2014). Using a special model, companies agree to cooperate with the government and pay heavy fines in exchange for a conditional promise by the American Department of Justice not to prosecute (Haugh, 2017). With a deferred prosecution agreement, corporations are compelled to adopt codes and compliance programs as part of the settlement agreement with the prosecution. This practice turns the adoption of compliance programs and codes into a non-voluntary act.

The adoption of a code and compliance program has often been used as the basis for establishing employee awareness regarding criminal norms, and as a basis for strengthening the possibility of convicting corporations.

For instance, in United States v. LSB Bank (United States District Court for the Eastern District of Pennsylvania, 1990), the court emphasized that, having embraced a compliance program and a code of conduct which were published and sent to all employees, they were well aware of their misconduct. Even though the code and compliance program that were distributed provided verifying and recording details of the individuals presenting financial transactions, it was not done in the relevant cases.

\section{Israeli jurisprudence: Adopting a negative approach to regulating CSR}

Israeli jurisprudence has adopted a negative approach, which reflects a perception of vast liability of corporations in criminal law, regardless of the adoption of codes of conduct.

In The State of Israel v. Rosenhoiz (Israeli Criminal Court of Jerusalem, 2010) which dealt with violations of anti-trust laws related to the Shufersal supermarket chain, the corporation adopted a meaningful code including norms relating to philanthropic contributions, according to which the corporation would contribute to charity and participate in community programs. Despite this meaningful code of conduct, however, the court rejected the claim that the adoption of a code should guaranty defense in criminal proceedings, and ignored the adoption of these codes.

The State of Israel v. Siemens (Israeli Criminal Court of Tel Aviv, 2017) involved a local branch of the international Siemens Corporation, whose managers were involved in bribery. The court emphasized that the adoption of a code of conduct, as well as a vast compliance program, could neither grant protection against criminal liability, nor serve to reduce the sentence.

These rulings raise problems since there is hardly any consideration of the adoption of codes of conduct. Hence, there is no incentive for corporations to adopt such codes.

\section{Regulating CSR: which approach should be applied?}

Courts should deny the negative approach and formulate the regulation of CSR within criminal law, while granting corporations protection against criminal liability. There are a few arguments in support of denying the negative approach and embracing the ethical CSR regulatory approach.

First, even-though it could be argued that traditional state-centered regulation is preferable because of the ability to employ criminal sanctions and enforcement, the claim should be rejected. Without recognition of self -regulation within the law, corporate policies will either ignore ethical demands, or adopt basic codes which mainly focus on maximizing profits. Corporate policies which focus largely on meeting deadlines, efficiency, and financial goals might lead to extended wrongful behavior (Walsh and Pyrich, 1994).

Regulating codes of conduct via criminal law 
PAP

24,1

As opposed to traditional state law, which is formal, general, and rigid, and uses classical tools of command and control, meta-regulation, employed within the ethical CSR approach, is more flexible and easily adaptable to changes in the external environment and to the specific circumstances of each corporation (Potoski and Prakash, 2005). It takes advantage of the inherent capacity of corporations to manage themselves and control their employees.

It also takes advantage of the knowledge and expertise of individual corporations, which know themselves and their culture best, and which recognize the specific steps needed to prevent potential violations of ethical norms (McBarnet, 2007; Shamir, 2004).

Second, even though it could be argued that the very essence of CSR is its voluntary characteristic, and that mechanisms of self- regulation regulated by the legal system, undermines the original concept of CSR, the claim should be rejected.

We should bear in mind that employing an ethical CSR regulatory approach preserves the voluntary dimension of CSR. According to this approach, organizations are self-determined to adopt a meaningful code. Even so, corporations might decide not to take upon themselves extra obligations and might instead comply only with the criminal code.

Furthermore, the gap between striving to preserve CSR as a voluntary act and regulating CSR, which has enforcement power, only characterizes the legislative CSR. The problem invoked by the legislative CSR regulatory approach has been driven by regulations aimed at gaining compliance with the standards of the criminal code only. Nevertheless, the regulatory approach of ethical CSR is advantageous in its adoption of thick codes, which include voluntary ethical norms beyond compliance. Hence, the approach preserves the very notion of CSR, which was originally supposed to reflect activities beyond compliance. Embracing the ethical CSR regulatory approach maintains the concept of CSR presented as actions by corporations (Parker, 2007). These ethical norms are not codified into the criminal code, but are nevertheless expected to be followed by stakeholders and by society.

The problem presented above is derived from the fact that, in the American system, corporations are compelled to adopt codes of conduct, since non-adoption is a factor in determining sentences, and results in more severe penalties. It is also used to force organizations to adopt compliance programs through plea-bargaining intended to avoid trial. Nevertheless, embracing a new approach, according to which non-adoption of codes would not be considered in the sentencing stage, would preserve the voluntary characteristics of the CSR.

The new ethical CSR approach should therefore be adopted, since it presents a solution to the problems of both the Israeli and American CSR systems. Under the Israeli system, denying the negative approach will create an incentive for corporations to adopt codes of conduct.

Under the American system, the adopted codes of conduct often lack true legitimacy, mainly because they are only criminal law-driven compliance programs concerned with avoiding law enforcement, rather than building a substantive ethical organizational culture (Haugh, 2017). Applying the ethical CSR approach will result in adopting efficient codes of conduct.

Third, even though it could also be argued that organizations that employ any CSR regulation necessarily establish the motivation for adopting CSR practices, that claim should be rejected.

Indeed, if CSR remains purely voluntary, it could lead to a symbolic adoption that is unaccompanied by genuine organizational change. For instance, a bus transport corporation could adopt voluntary codes and paint its buses green, while still causing pollution. The very possibility that the self-regulation practice could be tested in courts one day may lead to a fundamental organizational change when voluntary practices are applied.

One of the motivations for adopting codes, beyond the direct legal benefits, is societal response and stakeholder expectations. As scholars have noted, many consumers over the 
last decade have been switching to more socially responsible products, reflecting a shift towards higher levels of ethical concern in consumer purchasing decisions (Freestone and McGoldrick, 2008).

Regarding the motivation for corporations to adopt CSR, we should bear in mind that CSR was developed partly in an attempt to advance financial performance by attracting consumers, and partly for institutional reasons (Marquis et al., 2007), such as legalities and regulations (Karassin and Bar-Haim, 2019). Yet, beyond the motivation of avoiding direct legal consequences, CSR literature presents societal pressure as a motivation for corporations to adopt it. Placing liability on corporations affects their image and reputation. Corporations will try to avoid criminal liability as they take into account societal influence as a dominant motivator for adopting CSR.

In this vein, granting liability protection only to corporations that develop thick codes would then be an incentive for adopting meaningful codes of conduct. Companies wishing to preserve a good image would be motivated to do so. The idea of granting protections only to corporations adopting a thick code is based on the view of CSR as deriving from societal expectations, and not as a practice aimed at granting mere legal protections.

The motivation of managers and employees to act and enforce ethical norms is an important element that is at the foundation of the rationale of applying meta-regulation of CSR. Managers and employees will enforce and comply with norms due to both intrinsic and extrinsic motivations (Feldman and Perez, 2009). The intrinsic motivation relates to selfinterests and beliefs, whereas the extrinsic motivation refers to external institutions and rules. In this respect, the ethical CSR regulatory approach combines the two motivations, as it emphasizes the role of voluntary acts based on organizational goals and aspirations, as well as the importance of legal procedures.

Furthermore, scholars have emphasized the influence of participation and trust in motivating the enforcement of norms within mechanisms of self- regulation (Feldman and Perez, 2009). In this respect, the managers and organizations will find incentives for complying if they participate in designing the ethical norms they will adopt. This trust-based approach means that if a genuine thick code is adopted, a criminal law conviction would be no longer necessary. In this vein, it has been claimed that the managers' willingness to both comply with ethical norms and expect ethical behavior is derived from an ethical concern and a belief in the legitimacy of the norm (Gunningham et al., 2005; Feldman and Perez, 2009). The ethical CSR regulatory approach that the framework of meta regulation enables, includes selfregulation and is derived from the motivational belief in the legitimacy of the norms within the code designed and enacted by the firm itself.

Fourth, although it could be claimed that the current regulations of CSR are not efficient, taking into consideration that compliance programs in the United States have actually not reduced corporate crime levels (Wellner, 2005), the ethical CSR regulatory approach should still be embraced.

Indeed, compliance programs in the United States are often aimed at pushing employees into hiding and covering evidence of wrongful behavior. This could lead to compliance training being used, not as a means of generating lasting norms of ethical behavior, but as a tool applied only to shield the corporation from liability. Companies might direct employees to limit the mention and tracing of wrongful behavior, rather than eliminating the behavior itself.

Indeed, the adoption of thin codes within the legislative CSR of the American system is problematic, since it does not include added value beyond the existing law. Nevertheless, adopting an ethical CSR regulatory approach could be a solution.

Promoting legislative CSR and the adoption of codes which reflect the law will not result in preventing unethical behavior, but will result in lowering the level of ethics within the corporation, since employees will consider any voluntary ethical norms beyond the code as
Regulating codes of conduct via criminal law 
unnecessary. Employees will treat unethical behavior which is not covered by the code as legitimate and hence, will conduct various unethical activities.

Both the Israeli and American jurisprudence have evolved in such a way that adopting meaningful codes of conduct may worsen corporations' legal situation. Once a corporation adopts ethical norms beyond the law, it is bound to comply with its own policy statement. A corporation adopting a policy statement that it does not properly implement may expose itself to greater liability than it would have had it adopted no code at all. Hence, any implementation of code which includes ethical norms beyond the demands of the law itself exposes corporations to greater liability. Under these circumstances, corporations are driven to avoid adopting a code of conduct, or may only adopt a thin code reflecting the demands of the existing law that the corporation is bound to comply with anyway.

Indeed, many codes of conduct in the American system are not efficient, and focus only on prohibiting behavior against the firm itself by its employees, including behavior which impacts profits, such as, theft from employers and misusing corporation assets. Nevertheless, an ethical CSR regulatory approach would require corporations to implement norms with a genuine added value of ethics preventing criminal behavior regarding stakeholders and the public in general.

Furthermore, corporations are mainly motivated by societal pressure, and the very act of holding a corporation liable affects their reputation. Social norms play an important role as incentives for the enforcement of ethical conduct (Feldman and Lobel, 2010). The adoption of CSR practices is mostly driven by the desire to meet stakeholder expectations, including the ethical expectations of customers and the public. The possibility of a reduced fine is not a solid enough motivation for corporations to change their unethical behaviors and adopt thick codes accompanied by ethical behavior, since corporations will still be held liable. As long as corporations are still held criminally liable in a way that damages their reputations, the motivation for adopting meaningful code will be weak. Convicting corporations in criminal law has implications on the perception of the corporation among stakeholders. Receiving exemption from criminal liability by adopting thick codes is a much stronger motivation for corporations to reform their ways and meet social expectations. The possibility, therefore, of gaining protection from criminal liability has advantages for corporations beyond saving extra payment on fines and the legal consequences of conviction.

The American case shows that courts do not examine the content of the codes, but only examine the measures taken regarding compliance programs when sentencing. Hence, American courts do not require thick codes as a precondition for granting reduced sentences. The legislative CSR regulatory approach focuses on the inner mechanism for compliance with the requirements of the law itself.

As long as CSR regulation only demands compliance with the law, it will not motivate corporations to adopt meaningful codes. This is contrary to the basic goals of CSR which aims at advancing ethics and social citizenship of corporations. Such regulation, which advances legislative CSR, could even result in downgrading the level of ethics within corporations.

Fifth, the argument could be made that assigning extra duties results in extra costs, thereby affecting the efficiency and financial goals of corporation. Yet this claim should be rejected, because extensive demands regarding ethics do not necessarily raise costs, but only require ethical standards and decency. Furthermore, corporations are not required to take upon themselves these demands, but instead are granted protection when they voluntary adopt them. The exemption granted to corporations eventually saves money and the payment of costs and criminal fines. Preserving a good reputation by avoiding conviction in criminal law also saves money.

Finally, although it could be argued that it is problematic to raise demands which go beyond those required by the criminal code. Despite the legislature's sovereignty in 
determining the policy regarding criminal offences and the requirement of extra involvement of the courts themselves, the claim should be rejected.

As professional bodies detached from political agendas and pressures, the courts are advantageous in dealing with ethical issues, unlike elite groups and corporations, which often have close connections to the political arena (Litor, 2019a; Litor, 2019b; Litor et al., 2020).
Regulating codes of conduct via criminal law

\section{Adopting a new approach for regulation of CSR: presenting ethical CSR regulatory approach}

A few guidelines will facilitate implementation of the suggested ethical CSR regulatory approach. Contrary to the situation in the United States, where non-adoption of a code is considered when determining sentences, the adoption of ethical codes should remain voluntary. The adoption of such codes should only benefit corporations. In addition, managers should not be liable for choosing not to adopt codes.

Protection from criminal liability should be granted only to those corporations who embrace a thick code of conduct reflecting corporate social responsibility and hence the content of the code and the specific norms adopted should be examined.

There are a few parameters for thick codes.

(1) The code should include ethical norms beyond the requirements of the criminal code itself.

(2) A code aimed only at avoiding risks to the corporation and maximizing profit would not suffice. Hence, the enforcement of offences and norms regarding the employer, such as conflict of interests would also not be adequate. The code of conduct must be focused at preventing unethical behavior.

(3) In accordance with the stakeholder theory we should evaluate whether the code includes norms which go beyond the relationship of employees and the corporation, to address issues related to various stakeholders. Thick codes should also advance dissenting behavior to different stakeholders. Thick codes would include offences aimed at the public interest and society in general, such as antitrust laws or bribery and fraud.

(4) Codes of conduct may range from general ethical guidelines to very specific policies intended to prevent employees from committing particular types of crimes. In Israel, codes of conduct tend to be very general. It is therefore essential for corporations to adopt concrete guidelines. Regulation CSR must be aimed at ensuring that the norms of the ethical code are in accordance with the practice and structure of the specific corporation, and avoiding the specific risks that revolve the activities of the corporation. It is of special importance when a risky field is involved that is more prone to problems.

(5) In cases involving a history of repeated violations by a corporation, the code should be aimed at preventing these specific violations.

(6) Meaningful codes should include philanthropic contributions and activities for the benefit of the community.

(7) A code of conduct needs to have been enacted before a specific violation of law occurs.

(8) Codes should be aimed at preventing severe offences with large ramifications for the public, such as violations regarding work safety, and infractions that can potentially endanger the life or body. 
PAP

24,1

\section{0}

(9) If a corporation supplies essential services, it is particularly important to grant it protection against criminal liability.

(10) The various actors associated with corporations, such as contractors, subcontractors, and agents, should be required to comply with the code of conduct. Corporations should be liable for violations of either its employees or contracted bodies. The test should be the control the corporation has on the acts of its associated organizations.

(11) Instead of using deferred prosecution and non-prosecution agreements such as plea bargains, as is the custom in American law, liability and sanctions should be determined only by the courts themselves.

(12) The compliance program itself should include several principles which create proportionality and transparency and communication to all employees. In some cases, a corporation would be expected to adopt special measures within a compliance program including internal discipline tribunals with the authority to place sanctions on employees who do not comply with the ethical code. For instance, large corporations with many employees, international corporations, and public corporations owned by the state or a local municipality would be expected to adopt more meaningful norms and compliance programs

Table 2 presents the difference between the suggested approach - ethical CSR regulatory approach and legislative CSR regulatory approach.

\begin{tabular}{|c|c|c|}
\hline & $\begin{array}{l}\text { LEGISLATIVE CSR } \\
\text { REGULATORY APPROACH }\end{array}$ & $\begin{array}{l}\text { ETHICAL CSR } \\
\text { REGULATORY APPROACH }\end{array}$ \\
\hline $\begin{array}{l}\text { Whether corporations are } \\
\text { granted protection in } \\
\text { criminal procedure upon } \\
\text { adopting codes? }\end{array}$ & Reduction of sentences & $\begin{array}{l}\text { Granting protection against } \\
\text { criminal liability }\end{array}$ \\
\hline $\begin{array}{l}\text { What is required for } \\
\text { granting benefits within } \\
\text { criminal proceedings? }\end{array}$ & $\begin{array}{l}\text { Procedural demands - adopting } \\
\text { adequate compliance program }\end{array}$ & $\begin{array}{l}\text { Demands regarding content } \\
\text { and norms beyond procedure }\end{array}$ \\
\hline $\begin{array}{l}\text { Whether focused on } \\
\text { compliance with the law? }\end{array}$ & $\begin{array}{l}\text { Demands thin codes: Demands } \\
\text { compliance only with the criminal code }\end{array}$ & $\begin{array}{l}\text { Demands thick codes- reflecting } \\
\text { voluntary ethical norms beyond } \\
\text { - compliance }\end{array}$ \\
\hline $\begin{array}{l}\text { Which kind of norms are } \\
\text { included? }\end{array}$ & $\begin{array}{l}\text { Focuses on norms regarding the } \\
\text { employer- risks to the corporation and } \\
\text { profit }\end{array}$ & $\begin{array}{l}\text { Focuses on additional norms, } \\
\text { regarding various stake holders } \\
\text { beyond the employer and } \\
\text { concerning the public - interest } \\
\text { and social expectations }\end{array}$ \\
\hline $\begin{array}{l}\text { Is a philanthropic } \\
\text { contribution needed? }\end{array}$ & Not needed & needed \\
\hline $\begin{array}{l}\text { Does a general code } \\
\text { suffice? }\end{array}$ & General principles & $\begin{array}{l}\text { Addressing specific risks of the } \\
\text { cooperation and repeated } \\
\text { violations, and severe offences }\end{array}$ \\
\hline Who the code relates to? & Covers actions of employees & $\begin{array}{l}\text { Covers actions of all contractors } \\
\text { and sub- contractors }\end{array}$ \\
\hline $\begin{array}{l}\text { Cases of non -adoption of } \\
\text { codes }\end{array}$ & $\begin{array}{l}\text { Non adoption is considered in sentencing } \\
\text { and corporations are compelled to adopt } \\
\text { code of conduct }\end{array}$ & $\begin{array}{l}\text { Non adoption of codes is not } \\
\text { considered }\end{array}$ \\
\hline
\end{tabular}

Table 2.

Typology of CSR regulatory approaches and corporations are compelled to adopt code of conduct 


\section{Conclusion}

Criminal law in many countries has recognized the possibility of holding corporations liable for criminal acts. The development of CSR practices in the last few decades has raised the issue of whether and how CSR practices should be regulated within criminal law. Should the adoption of codes of conduct grant protection to corporations against criminal proceedings?

Drawing on the Corporate Social Performance model (CSP) and the institutional dimension of the pyramid of CSR (Carroll, 1991), the paper discusses distinct approaches to the regulation of corporate liability: a negative approach which denies the regulation of codes; a legislative CSR regulatory approach; and an ethical CSR regulatory approach.

These distinct approaches relate to the different patterns of CSP typology presented: the adoption of thin codes within legislative CSR, and the adoption of thick codes within ethical CSR. Legislative CSR requires merely the adoption of thin codes reflecting compliance with the current legal standards of the criminal code, while ethical CSR requires thick codes that reflect the adoption of ethical norms beyond compliance and social citizenship. As a possible motivation for adopting CSR, the paper suggests a novel solution regarding the regulation of CSR that grants protection to corporations from criminal liability.

American law has embraced a legislative CSR regulatory approach that is reflected in the sentencing moderation doctrine, which takes into consideration the adoption of codes of conduct and compliance programs in determining sentences in criminal law. Establishing inner compliance programs leads to lighter sentences in criminal proceedings, while neglecting to adopt such codes leads to more severe penalties. Nevertheless, the sentencing mediation doctrine has, for the most part, not led to the prevention of criminal acts by employees. This also raises a concern, since corporations that conduct themselves ethically are held responsible for the acts of individual employees which may be contrary to the expressed instructions of management. As opposed to American law, Israeli law has adopted a negative approach which ignores the development of CSR practices.

Both the American and Israeli approaches should be rejected in favor of a new approach. The new approach, ethical CSR regulatory approach supports granting corporations protection against criminal liability if they develop thick codes. This could be a novel solution for self-regulation practices within criminal law, as it advances the adoption of genuine meaningful codes of conduct and changes organizational culture.

\section{References}

Bucy, P.H. (2009), “Corporate criminal liability: when does it make sense?", American Criminal Law Review, Vol. 46, pp. 1437-1458.

Carroll, A.B. (1979), "A three-dimensional conceptual model of corporate performance”, The Academy of Management Review, Vol. 4 No. 4, pp. 497-505.

Carroll, A.B. (1991), "The pyramid of corporate social responsibility: toward the moral management of organizational stakeholders”, Business Horizons, Vol. 34 No. 4, pp. 39-48.

Carroll, A.B. (1999), "Corporate social responsibility: evolution of a definitional construct", Business and Society, Vol. 38 No. 3, pp. 268-295.

Carroll, A.B. (2000), "A commentary and an overview of key questions on corporate social performance measurement”, Business and Society, Vol. 39 No. 4, pp. 466-478.

Carroll, A.B. (2016), "Carroll's pyramid of CSR: taking another look", International Journal of Corporate Social Responsibility, Vol. 1 No. 1, pp. 1-8.

Evans, C.L. (2011), “Case for more rational corporate criminal liability: where do we go from here?”, Stetson Law Review, Vol. 41, pp. 21-40.
Regulating codes of conduct via criminal law 
PAP

24,1

Freeman, R.E. (1984), Strategic Management: A Stakeholder Approach, Pitman Publishing, Boston.

Freestone, O.M. and McGoldrick, P.J. (2008), "Motivations of the ethical consumer”, Journal of Business Ethics, Vol. 79 No. 4, pp. 445-467.

Gallo, J.N. and Greenfield, D.M. (2014), "The corporate criminal defendant's illusory right to trial: a proposal for reform", Notre Dame Journal Ethics and Public Policy, Vol. 28, pp. 525-548.

Gunningham, N.A., Thornton, D. and Kagan, R.A. (2005), "Motivating management: corporate compliance in environmental protection", Law and policy, Vol. 27 No. 2, pp. 289-316.

Haugh, T. (2017), “The criminalization of compliance”, Notre Dame Law Review, Vol. 92, pp. 1215-1270.

Israeli Criminal Court of Jerusalem (2010), "The State of Israel v. Rosenhoiz case 118/10", 16 July, available at: http://hegbelim.bvtech.co.il/subject/147/item/33211.aspx (accessed 26 September 2020).

Israeli Criminal Court of Tel Aviv (2017), “The State of Israel v. Siemens, criminal case 436805/16”, 16 July, available at: https://he.afiklaw.com/caselaw/5101 (accessed 28 September 2020).

Karassin, O. and Bar-Haim, A. (2015), "Explaining corporate social performance through multilevel analysis", in Lez, R.-B. and Philip, R.W. (Eds), Corporate Responsibility and Sustainable Development: Exploring the Nexus of Private and Public Interests, Routledge, London, pp. 131-148.

Karassin, O. and Bar-Haim, A. (2019), "How regulation effects corporate social responsibility: corporate environmental performance under different regulatory scenarios", World Political Science, Vol. 15 No. 1, pp. 25-53.

Litor, L. (2019a), "Constitutionalism and anti-privatisation strikes: introducing an eclectic model”, Israel Law Review, Vol. 52 No. 3, pp. 327-366.

Litor, L. (2019b), "The rise of an anti-global doctrine and strikes in public services", in Pellissery, S., Mathew, B., Govindjee, A. and Narrain, A. (Eds), Transformative Law and Public Policy, Routledge, India, pp. 26-48.

Litor, L., Menahem, G. and Bar-Mor, H. (2020), "The rise of the regulatory constitutional welfare state, publicization, and constitutional social rights: the case of Israel and Britain", The ANNALS of the American Academy of Political and Social Science, Vol. 691 No. 1, pp. 189-205.

Lobel, O. (2004), "The renew deal: the fall of regulation and the rise of governance in contemporary legal thought", Minnesota Law Review, Vol. 89, pp. 342-470.

Marquis, C., Glynn, M.A. and Davis, G.F. (2007), "Community isomorphism and corporate social action", Academy of Management Review, Vol. 32 No. 3, pp. 925-945.

McBarnet, D. (2007), "Corporate social responsibility beyond law, through law, for law: the new corporate accountability", in McBarnet, D., Voiculescu, A. and Campbell, T. (Eds), New Corporate Accountability, Cambridge University Press, Cambridge, pp. 9-58.

Parker, C. (2007), "Meta regulation: legal accountability for corporate social responsibility", in McBrnet, D., Voiculescu, A. and Campbell, T. (Eds), New Corporate Accountability, Cambridge University Press, Cambridge, pp. 207-241.

Potoski, M. and Prakash, A. (2005), "Green clubs and voluntary governance: ISO 14001 and firms' regulatory compliance”, American Journal of Political Science, Vol. 49 No. 2, pp. 235-248.

Shamir, R. (2004), "Between self-regulation and the alien tort claims act: on the contested concept of corporate social responsibility", Law and Society Review, Vol. 38 No. 4, pp. 635-664. 
United States Court of Appeal Second Circuit (2009), "United States v. Ionia management S.A. 555 F3d 303. 2007”, 20 January, available at: https://www.casemine.com/judgement/us/ 59146871add7b049342c4fe1 (accessed 28 September 2020).

United States District Court for the Eastern District of Pennsylvania (1990), "United States v. LSB Bank-New York, 757 F. Supp. 496 1990”, 25 July, available at: https://aw.justia.com/cases/ federal/district-courts/FSupp/757/496/1648847 (accessed 26 September 2020).

United States District Court for the Northern District of Illinois (2006), "United States v. Caputo 456F. Supp. 2d 970", 27 February, available at: https://casetext.com/case/us-v-caputo-3 (accessed 26 September 2020).

United States Sentencing Commission (2018), "2018 Guidelines manual annotated, 18 U.S.C. 3551", available at: https://www.ussc.gov/guidelines/2018-guidelines-manual-annotated (accessed 26 September 2020).

Walsh, C.J. and Pyrich, A. (1994), "Corporate compliance programs as a defence to criminal liability: can a corporation save its soul?", Rutgers Law Review, Vol. 47, pp. 605-692.

Wellner, P.A. (2005), "Effective compliance programs and corporate criminal prosecutions", Cardozo Law Review, Vol. 27 No. 1, pp. 497-528.

Wood, D.J. (1991), "Corporate social performance revisited", Academy of Management Review, Vol. 16 No. 4, pp. 691-718. 
PAP

24,1

34
Appendix

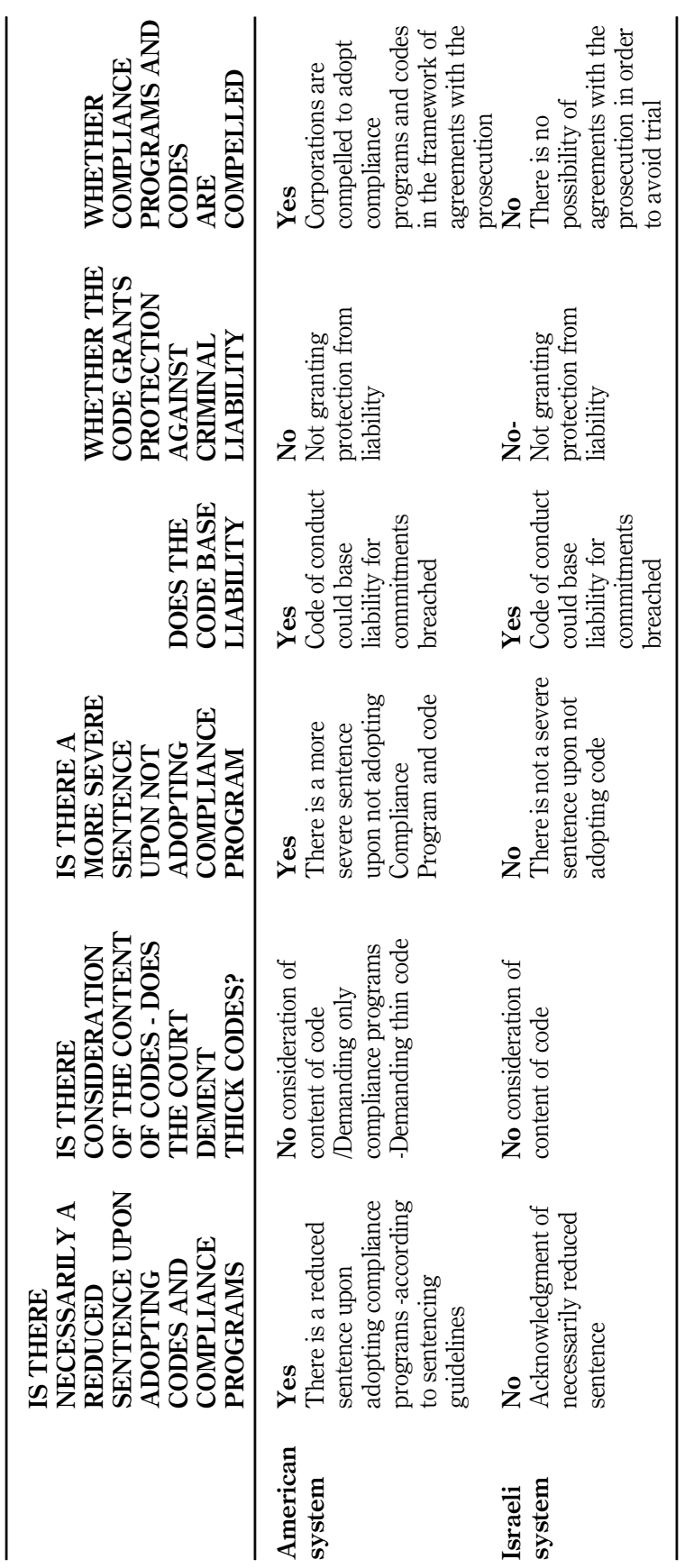

8 .

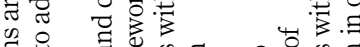

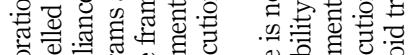

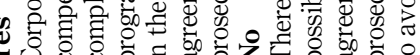

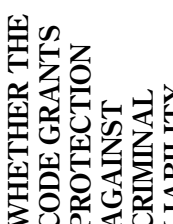

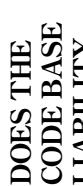

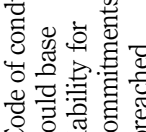

Table A1.

American system versus Israeli system 
About the author

Lilach Litor is a Lecturer at the Division of Public Law and Public Policy at The Open University of Israel. Her research focuses on the intersection of public law and public policy. She studies issues of corporate social responsibilities and regulation and governance. Her recent publications, such as article in Israel Law Review, focus on regulation of labor relations and social rights. Lilach Litor can be contacted at: lilachli@openu.ac.il
Regulating codes of conduct via criminal law

For instructions on how to order reprints of this article, please visit our website: www.emeraldgrouppublishing.com/licensing/reprints.htm Or contact us for further details: permissions@emeraldinsight.com 